\title{
2 \\ The diversification of return: Banaban home islands and movements in historical perspective
}

\author{
Wolfgang Kempf
}

\section{Abstract}

The international return mobility of the Banaban community has been significantly influenced by post-Second World War collective resettlement and the resulting transnational space of multiple belongings. Thus, with their politics of translocal linking of original and new home islands, the first generation of Banabans prepared the way for crossborder movements between Fiji and Kiribati. The central issue here is a historical development that extends from the organised return of younger Fiji-Banabans - as part of the repossession politics of the island of origin, Banaba, during the 1970s — and the more recent migration of members of the second and third Banaban generations to the capital atoll Tarawa in Kiribati through to imaginings of return from Tarawa to Rabi Island in Fiji, should the atoll country be rendered uninhabitable following possible future climate changes and subsequent rising sea levels. Viewed over the course of time, the directions and places of return have proven multiple 
and mutable. This diversification of return mobility is the product of the historical practices of different generations of Banabans in the context of a networked world of Pacific islands and island states.

\section{Introduction}

In this paper, I shall examine the phenomenon of international return mobility among diasporic Banabans. The Banabans' original home was the island of Banaba (also known as Ocean Island), now part of the central Pacific state of Kiribati. Discovery and exploitation of phosphate reserves on the Banabans' island of origin led to the British colonial authorities deciding to relocate the whole community to distant Fiji. Involuntary collective resettlement is a form of (forced) migration that hardly features in the literature on international return migration. This is due primarily to the fact that large-scale displacements and relocation of individuals and communities, such as those caused by natural and technological disasters, but also by large infrastructure projects, almost always occur within a single national framework (see Cernea and McDowell 2000: 1; Oliver-Smith 2009a: 3-4; 2009b: 129-132). Furthermore, the prospect of those affected ever returning is slim indeed, especially in the case of development-forced displacement and resettlement, as a result of subsequent radical transformations to the zones of origin (see OliverSmith 2009a: 4). As opposed to research on resettlement, migration studies in the field of diaspora and transnationalism focus mainly on the individual members of households or families who emigrate in the hope of a better life, act within transnational networks and, at times, initiate return movements (see for example, Brettell 2015: 151-153; Cassarino 2004). The focus has also widened to include return mobilities exhibited by descendants of the first generation, the so-called 'next generations' (Conway and Potter 2009a, 2009b; cf. Potter et. al. 2005).

In the Banaban case, collective resettlement and transnational migration, two areas that are usually kept separate, tend to intermingle. Thus community resettlement has an international character and is associated with return mobility, whereas transnational ties by Banabans living in Fiji and Kiribati originated in forced and collective migration. The analytic relevance of this case has its rationale in the historical sequence of displacement, resettlement, international migration and transnational ties, but also in diverse forms and phases of return mobility. On the 
conceptual plane, I take my bearings from Russell King and Anastasia Christou (2014: 2, 8-9), who introduced 'return mobility' as a generalising concept, further refining it into two distinct segments. One is 'return migration', in the sense of a voluntary return by a migrant to his or her country of origin - it might be just for a limited period of time or it could be permanent. The second and wider notion of 'return' includes voluntary and forced return but also variants of return mobility that are imagined or temporary (for example, brief visits). What matters most, from my perspective, is to resolve how the displacement and resettlement of the first generation impacts on the international return mobility exhibited by second and third generations. In this connection, I argue that over the span of 70 years a process of diversification of return mobility can be observed, based on the concepts of differentiation, reversal and ramification.

The concept of differentiation highlights the distinction between homeland and nation-state. The point is to advance an alternative perspective to 'methodological nationalism' (Wimmer and Glick Schiller 2002; Glick Schiller and Salazar 2013). When Banabans talk of homeland and returning there, they are not thinking of nation-states, but of islands; that is, for them, homeland and home island are congruent. The historical background explains why: the Banabans were collectively relocated from what was then known as the Gilbert and Ellice Islands Colony to the then Crown Colony of Fiji, where they were resettled on Rabi Island. Out of this transcolonial movement the first generation grew a vision of Banaba, the island from which they had been removed, as their ancestral homeland, a place that had to be protected and preserved for future generations and eventual resettlement. To shore up this vision and also for more pragmatic reasons, the settlers on Rabi Island decided to transfer the identity-conferring structures of ancestral Banaba to the landscape of their new island, duplicating the number and names of villages. With the backing of the colonial administration, they built their new home island into a geographically, politically and culturally distinct enclave within Fiji (Kempf and Hermann 2005). When Fiji and Kiribati achieved independence in the 1970s, Rabi and Banaba now found themselves in two different sovereign states; however, this hardly changed the historically sanctioned practice of equating homeland with home island (see Figure 1). 


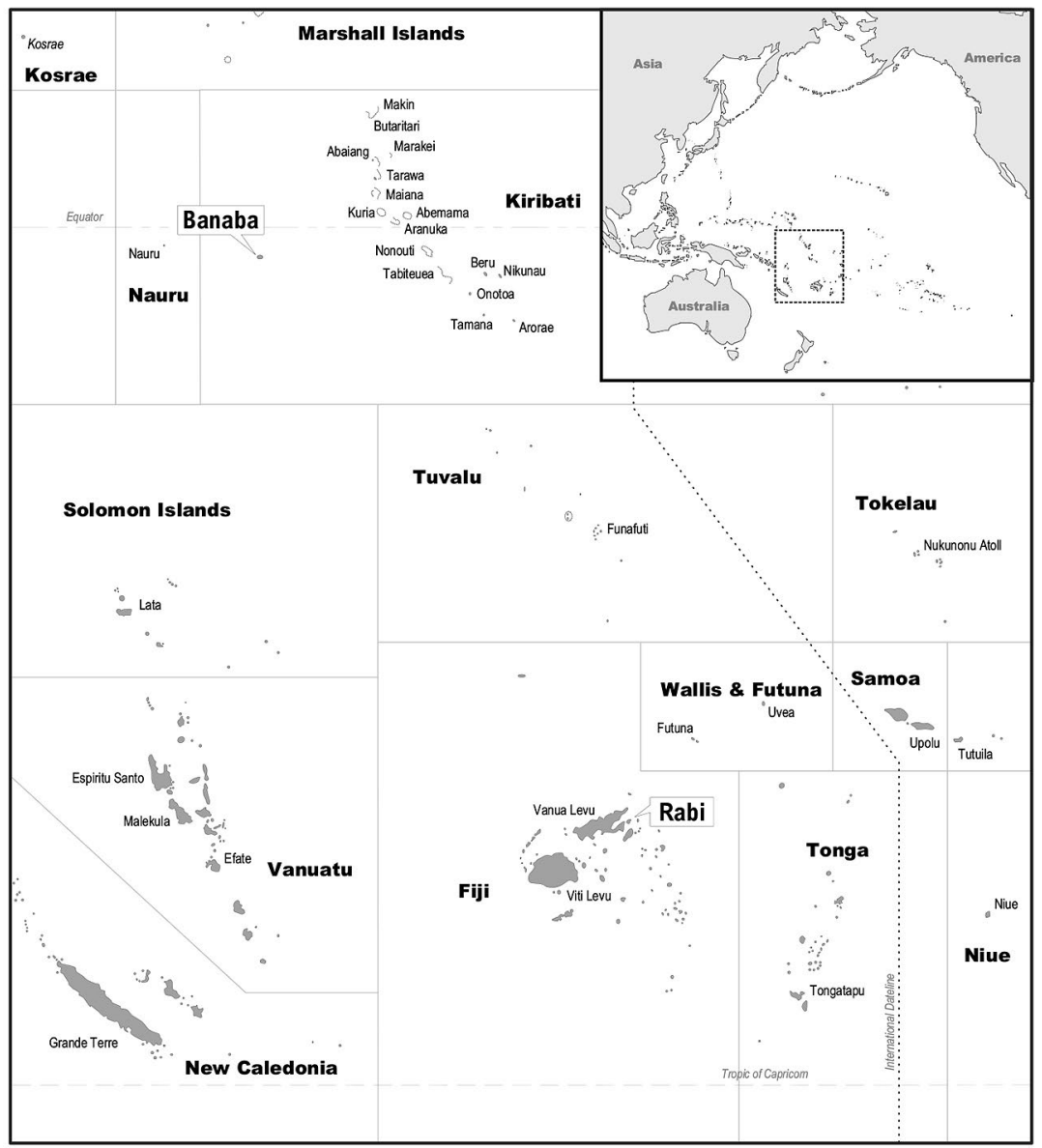

Figure 1: Section of map of Oceania showing the islands of Banaba (Kiribati) and Rabi (Fiji)

Source: Wolfgang Kempf.

Reversal is the name given to the direction of return. It signifies a development where the (at the time) newly acquired island of Rabi came to be prioritised as home island and place of return. In the early decades following resettlement, it was ancestral Banaba that stood at the heart of indigenous constructions of home and return. However, as a result of their determination to anchor in the collective memory of future generations the idea of two interconnected homelands-Banaba being the first (ancestral) and Rabi the second (acquired) - the pioneer generation simultaneously paved the way for new forms of identification. Thus the community came to see itself as a transnational ethnic minority, possessing not one but two 
home islands, each in a different sovereign state. In Fiji, the Banabans are known as an ethnic group inhabiting Rabi Island but also possessing an ancestral island in Kiribati, while being Banaban in Kiribati now implicates a second home island in faraway Fiji (Kempf 2012). This transnational terrain of multiple belonging enabled second- and third-generation Fijianborn Banabans to reverse their focus and primarily turn attention on Rabi Island in case of migration. Other studies of return migration interpret the reversal of homeland and return primarily through the perspective of transnational links between nation-states, with the second generation returning to their country of origin and maintaining links with their country of birth, now seen 'as a different kind of homeland' (King and Christou 2014: 6). Yet, when the idea of homeland and return, as in the Banaban case, is predominantly focused on islands within nation-states, as opposed to the nation-states themselves, a more nuanced approach will surely be needed.

To talk of ramification is to recognise the fact that Banabans not only live on their respective home islands, but frequently build island homes elsewhere in Fiji or Kiribati. Island homes are nodes of identification with Rabi and Banaba. When island homes lie outside the home islands, they are instrumental in altering the perspectives and directionality of return mobility. Ramification chiefly takes the form of migration into the urban centres of the two island nations - mainly Suva and Lautoka on Viti Levu in the case of Fiji, and Tarawa in that of Kiribati. For our analytic purpose, it is the international migration of second- and third-generation Banabans from Fiji to Kiribati that is of especial interest. The overwhelming majority of returnees do not settle on the home island of Banaba; rather, they have their sights set on Tarawa, the capital atoll. Were we to follow the postulate of congruence between home island and homeland, this would not seem to amount to a case of return mobility. In fact, Banabans only think of Banaba as homeland or motherland, not the main atoll of Tarawa and not the nation-state of Kiribati. On the other hand, Fiji-Banabans hold special rights, meaning that not only can they reside and work permanently in Kiribati, but they become citizens upon arrival. On top of that, many Banabans share intimate ties with Kiribati and its people, ranging from kinship ties (blood or marriage) to emotional ties of all kinds; nor should we overlook the many landholdings claimed by returnees (Hermann 2003). Such family, material and emotional references (cf. King and Christou 2014: 2) mean that when Fiji-Banabans migrate to Tarawa there 
is a real-world dimension to their return. ${ }^{1}$ Residing on Tarawa for FijiBanabans also holds the possibility of a reversal of return, since many prioritise Rabi Island (not Banaba) as their home island.

The first generation of resettled Banabans, via a politics of forging translocal linkage between island of origin and island of relocation, could widen the range of options open to the second and third generation for international migration and return within the region. This historically oriented study will prioritise the specifically regional nature of resettlement, migration, transnationality, and return mobility between islands and island states. Contrary to the South-South perspective I am following here, the bulk of studies dealing with return migration usually target migration flows from the 'global South' to the 'metropolitan global North' (Conway and Potter 2009a: 2-3). In Oceania, more specifically, this includes movements away from the small island states of the Pacific into metropolitan states like Australia, New Zealand or the USA (see for example, Lee 2003, 2009). To be sure, Banabans do emigrate to all of the above destinations. But this should be seen as a more or less recent phenomenon - and yet to be fully researched. For that reason, further consideration of this more recent migration flow (and its possible contribution to a further diversification of return mobility) is omitted here. ${ }^{2}$

Therefore, I shall focus on three historical pathways of return mobility. I begin with the politically motivated return movement from Rabi in Fiji to Banaba in the central Pacific during the 1970s and early 1980s. At the time, the resettled Banabans were intensifying their anticolonial struggle for indemnification and national sovereignty. A central plank in this struggle was the organised return by young, for the most part unmarried, Fiji-Banabans of the second generation, as part of a politics of occupying and resettling ancestral Banaba. The second return migration to be considered here is that of Fiji-Banabans to Tarawa, an influx that began in the 1990s and continues to this day. Despite many of the newcomers returning to urban Kiribati for educational facilities, scholarships and

\footnotetext{
1 For second-generation returnees in the Caribbean, Tracey Reynolds (2014) has analysed comparable aspects of ramification, albeit on the level of island states. Her argument, namely that strict adherence to a 'bi-polar origin-destination framework' does not always do justice to the realities of a region-wide return (Reynolds 2014: 86), shows structural similarities to the perspective developed here of a ramification of Banaban return mobility.

2 Of the metropolitan nations New Zealand probably now has the largest Banaban diaspora (cf. Teaiwa 2014). However, no exact figures are available on first-generation emigration and return mobility.
} 
job opportunities, this particular motivation shall not detain me here. Instead, I shall concentrate on the case of Fiji-Banabans seeking to reclaim family property on Tarawa. Return in such cases often resulted in disputes over land, a scarce resource on Tarawa. My third and last area of investigation is the return mobility exhibited by Banaban migrants living on Tarawa. Rabi Island is usually their preferred destination of return, whether for permanent relocation in advanced age, for short family visits or for imagined ones on the plane of contingency planning. Why the last one? Fiji-Banabans have, over recent years, been increasingly confronted with contemporary discourses on the considerable risks facing Kiribatian atoll state-from climate change and rising sea levels. Against this background, Fiji-Banabans on Tarawa are more mindful than ever that Rabi, a volcanic island, could one day offer a suitable place of refuge from the projected risks of environmental change-if only in the distant future.

Banaba, Tarawa, Rabi-all three destinations have, over time, drawn in members of the Banaban diaspora, indicating just how multiple and protean are the directions and places of return. The diversification of return combined with the constitutings of home island and island home are relational products of the historical agency manifested by various generations of Banabans, unfolding within a context of colonial and postcolonial structures in a networked world of Pacific islands and island nations.

\section{Relocation and the vision of return}

Following discovery of lucrative phosphate deposits on Banaba in 1900, Banaban islanders were confronted by unprecedented radical change. First came the British annexation of their island in 1901; then, some 15 years later, Banaba was included in the Gilbert and Ellice Islands Colony (GEIC). Powerless to stop this colonisation of their home island, the Banaban Islanders soon found themselves facing epidemics, land expropriations, resource destruction and racial segregation, not to mention the unstoppable expansion of an industrial and administrative infrastructure. The extraction of the island's high-grade phosphate reserves - first by the Pacific Phosphate Company, then, after 1920, by the 
British Phosphate Commissioners (BPC) ${ }^{3}$ — set in motion a veritable machinery of destruction, stripping the local population progressively and irreversibly of its land.

Soon it was clear that if mining continued much of Banaba would be rendered uninhabitable. Therefore, beginning in 1909, the colonial administration and phosphate company repeatedly floated scenarios that, in their final form, envisaged resettling the islanders elsewhere (see Williams and MacDonald 1985: 89, 148, 257). For many years the Banabans remained utterly and vehemently opposed to any such plans. But so massive was the scale of the forced expropriations, so progressive the inroads on their land, that eventually they integrated the idea of purchasing another island for the sake of future generations into their anticolonial discourse (see Maude 1946: 10-11). By the early 1940s, the Banabans were expressing the wish to purchase an island in Fiji, also a British colony. Finally, in March 1942, the Western Pacific High Commission in Fiji acquired the plantation island of Rabi on their behalf, using for that purpose money from the 'Banaban Provident Fund', which was administered by the commission. Rabi Island, belonging at the time to Lever's Pacific Plantations Pty Ltd., was purchased for 25,000 Australian pounds (see Kempf 2011: 19-20; Maude 1946: 11-12).

Shortly thereafter, with the coming of the Second World War to the Pacific in August 1942, Banaba was occupied by the Japanese army. Logistic shortfalls led to the Japanese occupiers deporting the Banabans to the islands of Tarawa, Nauru and Kosrae (Maude 1946; Ellis 1946; cf. Hermann 2003; Kempf 2004). In the immediate aftermath of war, the British colonial administration seized the opportunity presented by the Banabans being scattered and displaced. Officials gathered the survivors-much weakened by disease and undernourishment - using Tarawa as a temporary collection point. Insisting that a return to Banaba was simply not possible due to warrelated destruction, the administration proposed that the Banabans might like to make a fresh start on Fijis Rabi Island. Finally, on December 15, 1945, some 703 Banabans and 300 Gilbert Islanders (who had been taken into the Banaban community) landed on their new island in Fiji (see Maude 1946: 12-13; Silverman 1971: 147-148). Despite major difficulties in the early years, chiefly due to the unaccustomed climate, the strange new

3 The governments of Great Britain, Australia and New Zealand decided in 1919 to jointly exploit the phosphate reserves. Each country had its own representative on the Board of Commissioners (Ellis 1935: 178-181; Macdonald 1982: 103). 
environment, and the bewilderment and deep-seated uncertainty afflicting the migrants, the majority of the Banabans decided, in a secret ballot held in May 1947, to make Rabi their future home. This decision, to which over 80 per cent of the Banabans gave their backing, was codified by the colonial administration in a 'Statement of Intentions', which was subsequently signed by the community's political representatives (see Silverman 1971: 167).

After a phase of spatial and social consolidation on Rabi Island, the Banabans intensified their political struggle, from the mid-1960s on, against what they saw as continued discrimination, exploitation and dispossession by the British colonial power and the BPC, the body responsible for the phosphate mining (see 'Banabans seek better phosphate deal' 1965; cf. Macdonald 1982; Silverman 1971). The chief negotiators for the Banabans attempted, via political channels, to manoeuvre the British government into a series of concessions. One of their core demands-political independence for Banaba in association with Rabi Island in Fiji-aimed at winning back control over land and phosphate, including a fair share of the profits in the form of royalties. They also pressed for the complete rehabilitation of terrain laid waste in the course of decades of high-intensity mining operations, so that they might, one day, be able to return to Banaba (or Ocean Island). In a memorandum to a petition the Banabans submitted to the United Nations in 1968, the community stated: 'We are deeply attached to Ocean Island because it is our homeland - the land on which God originally planted us ... We are, therefore, naturally anxious to return to our homeland and thereby preserve our national, racial and cultural identity' (National Archives of Fiji (NAF) High Court of Justice 1968: 7). A few pages later, they had this to say about their demand for independence:

[The Banaban people] seek political independence for Ocean Island as their homeland and the Rabi Island Council as the elected representatives of the Banaban people wishes to secure the agreement of the United Kingdom Government to the immediate granting of independence to Ocean Island and the re-establishment of our people there. The right of our people to independence on Ocean Island rests on the United Nations Declaration on the granting of independence to Colonial Countries and people ... The Banaban people intend to return to Ocean Island and, in terms of Resolution 1514 (xv), they 'have the right to self-determination, so that by virtue of that right they freely determine their political status and freely pursue their economic, social and cultural development' (National Archives of Fiji (NAF) High Court of Justice 1968: 13). 
The petition to the United Nations in June 1968 lent additional weight to their demands for sovereign status, financial compensation, terrain rehabilitation and the belated restoration of justice. Although the petition was formally directed at the UN, the real addressee was the British government of the day. A few months later, in October 1968, Banabans taking part in the Ocean Island phosphates discussions in London distributed a comprehensive demand catalogue, which was, however, rejected by Lord Shepherd, representing the government (see Foreign and Commonwealth Office 1968). The Banabans appealed the decision in 1970, but this was dismissed (see Posnett 1977: 5).

\section{Tauan Banaba - the politics of return}

Repeatedly rebuffed by the British government, the political leadership of the Banaban community finally resorted to legal action, lodging an appeal with the British High Court in London (see Binder 1977: 146167; Macdonald 1982: 268-269). One principal issue negotiated was compensation for the damage done to Banaba, another was rehabilitation of the island by the phosphate company. In parallel with legal action, Banaban leaders returned to an earlier demand that Banaba should be detached from the GEIC and awarded sovereign status. Accordingly, in 1974, they submitted a petition to this effect to the British government and the United Nations. The background to this move was the ongoing negotiations about, and the preparations for, granting independence to both the Gilbert Islands (later Kiribati) and Ellice Islands (later Tuvalu) (see Macdonald 1982: 263-275; Posnett 1977: 5).

In the course of the 1970s, with a view to underscoring these demands, the Banabans branched out into a politics of return. This historical phase is anchored in the community's collective memory as Tauan Banaba (literally 'Keep Banaba'), that is, physical occupation of the home island in order to forestall possible appropriation by other parties, especially Gilbertese Islanders (later I-Kiribati). Organised return was designed to signal the community's determination to uphold their ownership rights to their home island (cf. Hermann 2004:198). This, however was not the first time that members of the Banaban community in Fiji had returned to the land of their ancestors. As early as 1947, only a few years after their original relocation, the BPC had briefly brought a sizeable group of islanders back to do boundary marking (te tautia) so the remaining 
land could then be mined for phosphate (see Silverman 1971: 170-171). Twenty years later, a delegation of Banabans again set foot on the island. Shocked at the extent of its despoliation, they complained about what they saw as blatant infringements by the mining company against existing agreements, one particularly egregious case being the destruction of the Banabans' graveyard. ${ }^{4}$ Other Banabans also arrived on Ocean Island, having found work with the BPC (see for example, Posnett 1977: 10). Then, in March 1975, around 60 men-mainly young and unmarriedas well as four women left Rabi Island on the Ai Sokula, a vessel bound for Banaba. This was a political action, designed to garner publicity. In an article headlined 'Banabans set sail for their island home' The Fiji Times explained the rationale: "They say their move back to their old homeland is their way of telling the British-and the GEIC: "This island is ours".' ('Banabans set sail for their island home' 1975). Tom Teai, at the time Rabi administrator, publicity officer and co-organiser of the Tauan Banaba initiative, later recalled these events with the hindsight of 20 years:

I belonged to an age where fighting was the mood. You know. We were more aggressive back then. We had our objective-we had very definite objectives about Banaba. That concerned Banaban identity and Banaban separation and [the] political future of Banaba. You know ... They [the Banabans who went to Banaba] were just told [by the Banaban leaders]: 'Go there, take the place-while we go and fight our case. You physically take the place. We'll go and try and take it politically'. (Interview recorded 16 July 1998)

Docking at Banaba, the islanders had to wait before disembarking. The GEIC had declared Banaba a restricted area. This meant that the new arrivals could only visit their old home after being issued with special permits. In addition, a second vessel carrying tents for the returnees was delayed, so that they initially had to overnight on the Ai Sokula. Only later could they set up camp on dry land ('Ocean Island welcomes 60 from Fiji: Rabi settler group stays' 1975). Two years later, an official of the British government visited the island briefly; among other things, he reported on how the new settlers were faring. His impression of what he estimated to be 50 Banabans was of a largely marginalised and 'aimless' community, occupying huts partly constructed from the remnants of old, torn-down BPC buildings (Posnett 1977: 10-11).

4 See NAF 1968, Documents 46/1968.

5 All interviews cited in this chapter were conducted by the author. 
In the spring of 1979, Rabi's Council of Leaders again sent some 100 Fiji-Banabans across to Banaba to build upon their earlier foothold there (see 'Petrol bombs on Banaba' 1979: 22). The signs pointed to confrontation. The long and costly appeal to the High Court in London had not brought the desired success (see Macdonald 1982: 268-269). Worse, the Banaban leadership had ultimately failed in all its attempts to detach Banaba from the newly created state of Kiribati. Now installed on Banaba, the returnees organised a protest march and, later on, attempted to destroy machinery and other installations of the mining company, using improvised petrol bombs (see 'Petrol bombs on Banaba' 1979: 22). The radicalisation of the Banabans led to arrests, injuries and increased conflict pitting Gilbertese against Banabans, further deepening already existing rifts between the two groups. Integration of the island of Banaba into the new state of Kiribati in July 1979 could not be prevented by the Banabans, for all their many initiatives.

In that same year the phosphate mine on Banaba ceased operations. The last of the BPC workforce departed in January 1980 (Williams and MacDonald 1985: 522). One of the Fiji-Banabans, a man who in younger years had returned to occupy Banaba, reflected on this turning point, coinciding as it did with the closing of the mine. Here, then, is a passage from our conversation, which I reproduce at length because it gives a good account of his experiences as a returnee:

So I stayed there until BPC left. And it was very interesting thing to me, because we've been with [all the people], you know. The island was very, very noisy. [Later] the atmosphere was very different ... And it's a sad story, because at one time you were staying with lots and lots of people. Then all of a sudden they were all gone ... And then we-well, this is what I experienced. Before the boat left- the Europeans were leaving, so the boat came to pick them up. This was the last lot. I was watching them and along with my Banaban friends we stayed behind. We watched them, we said goodbye to them ... Now there was nobody else on the island except the police and the Gilbertese administrative people ... And then the Government of Kiribati tried to operate the lighting plant [on Banaba] ... But they couldn't afford it! [laughs] So that was that. That's when we experienced darkness. Like we were there with our greatgreat-grandfathers. And we were really happy. We lived happily on the island. Because here, on this island, we don't even have a power plant in our villages ... But we didn't mind. We didn't mind at all. And we said: 'Okay, we are back to square one. The phosphate company has abandoned this island. Abandoned us too. Without any water. Without any means of 
transport. So here we are-anyway—we're back to square one.' ... And that's what our experience has been. Life after BPC. And then the Kiribati Government, one way or another, tried to punish us - the Banabans. So it cut off communication with us. When the radio-the radio telephones on the island broke down, nobody from Kiribati came [to fix them] ... Even the food!

WK: So how did you survive then? I mean you had no food supply.

K: We are Banabans! We get by_we only eat fish. We eat fish only ... (Interview recorded July 24 1998)

The end of phosphate mining and the departure of the Europeans had, as these remarks by a second-generation returnee indicate, fundamentally transformed life on Banaba. Silence, darkness, isolation, deprivation and bare subsistence had become the new normal, marking a caesura in the island's fortunes. 'Life after BPC' generally exhibited aspects of liberation and a new beginning, but perhaps the main thing associated with it was the positive experience of returning to one's roots. This historical experience of consolidating ethnic awareness and cultural belonging went hand in hand with a newly achieved spatial control over the island. These factors, in combination, strengthened the hand of second-generation Banabans when it came to dealing with the small numbers of I-Kiribati living on their ancestral island as outsiders.

Now, this return to Banaba movement would have been unthinkable without close coordination from the political leadership and families back on Rabi Island in Fiji. This transnational terrain was a key prerequisite of what later followed: the reversal of return. Not all Fiji-Banabans of the second generation who returned to Banaba wanted to settle there permanently. So Rabi Island, the second home island, became a focus as a place of return. A woman of the second generation, who had grown up on Rabi but been sent to Banaba in 1979 by her politically active mother, recalled after 30 years the period following the BPC's departure:

By that time we had all gone our separate ways. Some of us were travelling back to Fiji and some staying behind ... I don't know, my heart just told me to stay behind. I really wanted to stay on Ocean Island. And-but that's another thing - my mum said: 'If you accept what I think, please stay there forever. You can come back. Save your money, if you want to come and see me.' ... So I stayed there during those years. That's when I became pregnant with my second daughter ... I wanted my daughter to be a citizen. A Fijian citizen. So I tried to save up and go back to Fiji 
to my mum, so I could have my baby there. That was in 1982 ... I really wanted to go back and have my baby there, because I knew that if you have your baby on Ocean Island, it will be very hard for them to go to school or back to Fiji, later on in the future ... I wanted my daughter to go to school in Fiji. Because I know the difference ... The difference is like this - in school it is very hard for people here [in Kiribati] to learn to speak English ... That's why I wanted my daughter to grow up and learn English in Fiji. (Interview recorded 3 October 2013)

This woman, too, had obeyed the call by the political leadership for a return to Banaba, culminating in the demonstrative reoccupation of their ancestral home. Yet their stay-at-home relatives on Rabi Island continued to loom large as a vital source of support and care. Especially for young parents with small children, the economic downturn and the hardships in a period of time after the mine had closed, not to say the differences in living standards and educational facilities between Kiribati and Fiji, were important reasons for retaining access to these social resources. Returning to Fiji and taking out Fijian citizenship was, in the opinion of many, a prudent move, bearing in mind the future prospects of their own children and the considerable difference it might make.

\section{Banaban migration to Tarawa}

Today the Banabans find themselves in the position of having two separate 'home islands' that are more than 2,000 kilometres apart and belong to two different Pacific island states. Rabi Island with a population of approximately 3,000 constitutes something of a political, social and cultural node for the Banaban diaspora. The great majority of secondand third-generation Banabans, whose common denominator is having been born and grown up on Rabi, look on this Fijian island as their primary home (see Hermann and Kokoria 2005: 129). Yet Banaba in distant Kiribati resonates across the generational divide as the identityconferring place of origin, to which Banabans everywhere feel bound by ancestry, traditions and land ownership, as well as collective narratives of exploitation, displacement and resettlement (see Kempf 2004; Hermann 2004; Kempf and Hermann 2005).

Ever since Kiribati won independence and all phosphate mining ceased, the task of administering and policing Banaba has been jointly handled by Kiribati officials on the one hand and the Rabi Council of Leaders, based in 
Fiji, on the other. Today the island is a largely marginalised place, bearing the traces of a defunct phosphate industry, including much dilapidated infrastructure. Official census data put the number of those living there at just over 300 (Secretariat of the Pacific Community 2007: 104). Aside from some I-Kiribati working on behalf of the government, most of the present population are Banabans and their families, ${ }^{6}$ employed by the Rabi Council of Leaders to work as stewards of the island. The State of Kiribati has granted the Banaban community special rights, now codified in the Constitution (see especially Chapter IX). These include extensive decision-making powers over Banaba, a seat in Kiribati's parliament and the provision of civil liberties within Kiribati (see Hermann 2006: Chap. 7; cf. Dagmar 1989: 206; Teaiwa 1997: 138). A core consideration here is that all Banabans upon entering Kiribati automatically acquire citizenship, and so enjoy an unrestricted right of abode.

When Fiji-Banabans travel to Kiribati they are 'going back' to a country in which their original homeland is now situated. However, in a development that goes back to the end of the 1990s, only rarely today does ancestral Banaba feature as the destination of return mobility; far more frequently the returnees have their sights set on Tarawa, at once Kiribati's capital and the largest atoll. According to my calculations, at least 600-700 Banabans from Fiji were living on Tarawa in 2013. Most had moved there for economic reasons. An important consideration was the highly restricted job market on Rabi Island and the low pay. The matter has been further complicated over the last three decades by the declining economic fortunes of the Rabi Council of Leaders (a body that is, along with the Fijian government, a principal source of jobs on Rabi) plus the often difficult economic situation that has overtaken Fiji generally, due not least to the coups and the resultant political instability.

When it comes to education, scholarships or simply finding work in Fiji, Banabans see themselves as frequently losing out to both Fijians and IndoFijians. Natan ${ }^{7}$ from Rabi, a Banaban man in his late 60s, explained the advantages he saw from living in Kiribati. He had held an administrative

6 Today a small core of permanently resident Banaban-born migrants of the first generation (that is, children of the second-generation returnees) are keen to distance themselves from the Fijianborn next generations.

7 All personal names of interview partners cited in this article are pseudonyms, except for Tom Teai. 
post on Banaba from the first half of the 1990s and well into the new millennium; at the time of our interview, he had been living for almost a decade on Tarawa, where three of his children had found good jobs:

$\mathrm{N}$ : I think one thing [my children] prefer here is that there's more advancement than on Rabi. More advancement. Yeah, you got a lot of chances here! Because the Kiribati government is in touch with the outside world. But Fiji is difficult! Because the Fijians are always there. The Indians are always there. And they're the ones who always stop Banabans. I mean they want all the jobs.

WK: Does that mean if you come here you have an advantage?

$\mathrm{N}$ : Well, more than in Fiji!

WK: Is that so?

$\mathrm{N}$ : Yes! I'm telling the truth. Take my children. Now, the Kiribati government knew they were my children. They were not brought up here, they were brought up in Fiji. But because they are part and parcel of Kiribati-they are Gilbertese too and they have a very good [general] understanding. So [the Kiribati government] didn't block their way. They gave them a chance. (Interview recorded 30 September 2013)

Migration from Rabi Island to Tarawa is, fundamentally, a cross-border movement of people exchanging rural for town life. As the seat of government-in that respect quite unlike the relative backwater that is Rabi-Tarawa offers an urban milieu with multiple links to the world beyond Kiribati. It is, moreover, a place with job openings and other entrepreneurial opportunities for Banabans. For the younger members of Banaban migrant families, there is the additional prospect of a scholarship to higher educational institutions, which could, in turn, lead to an early return migration, as most of these institutions are located in Fiji. Where Banaban migrants hold a singular advantage is that they not only arrive already fluent in the local vernacular, but also, owing to their long diasporic existence in Fiji, with a rather better command of spoken English than most of the I-Kiribati.

Especially important, in this connection, is that a sizeable number of FijiBanabans possess landholdings on Tarawa deriving from their close kinship ties with other I-Kiribati. The fact that such genealogical anchorings of place and identity provide a basis for Banaban migrants to search out land on Tarawa suffices, in my view, to talk of a 'mobility of return' in this connection. For Fiji-Banabans able to mobilise pre-existing social 
ties with Tarawa, land usually plays a significant economic role. Land, after all, is a scarce resource on this large, urbanised atoll; accordingly, its monetary value is high. By way of contrast, owning land on ancestral Banaba, an island still scarred from phosphate mining and marginalised within Kiribati, is of secondary importance in today's economic realities. Back on Rabi, land is allocated to resident Banabans for private use and cannot be alienated; it is held de jure as the collective possession of all Banabans, as represented by the Rabi Council of Leaders. Land on Tarawa, to the contrary, can be used in a variety of ways, ranging from residential and business premises for an extended family to a source of added income from leasing and sale (see Namai 1987: 31-32; Paterson and Itibita 2013: 94-95, 97).

The status of land on Tarawa, at once scarce and controversial, makes returning there anything but an easy choice for Fiji-Banabans. Natan, the second-generation Banaban from Rabi quoted above, points to a problem his fellow Rabians sometimes face on this urban atoll. Although his family does not hold land on Tarawa itself, but on one of Kiribati's larger outer islands, he enunciates a widespread Banaban sentiment of ambivalence regarding the legal and ownership status of at least some land in this context:

Some already came [over] and [wanted to] find their home-I mean their land. Because many people on Rabi own land on Tarawa. And some came back and then died, you know. Because they were destroyed by te wawi [sorcery] ... Because [the owners from Rabi had] been away quite a long time. And these [local] people they told the land department that: 'No, they have [all] died.' And all of a sudden, they [that is, the Banaban owners from Rabi] came. The right people. But the land was already sold to somebody else. Very interesting. Very interesting. This is how the land on Tarawa is-very upside down. (Interview recorded 30 September 2013)

The charges of sorcery which many Fiji-Banabans level against I-Kiribati point to social tensions, confrontations and fault lines elicited by the claims of returning landowners. In isolated instances, Banaban returnees try to avoid conflicts of this kind. Tera, a third-generation Fiji-Banaban who grew up on Rabi but had emigrated with her (now divorced) husband 10 years earlier to Tarawa, decided not to enforce her land claims. The reason was she feared being targeted by her opponents for sorcery: 
We got the land. But we don't want to go and stay [there]. Because here are so many magicians [laughing]. Witchcraft! ... Like so many people from Rabi came over for the land and they died here ... [T] hat's why we were afraid. We just leave [them] our land, because we can survive [without it]. That's why we never bothered about the land. If we were not qualified and had come over-[say] we couldn't make a living, find a way to live or [get] a job, then we would seek to get our land back. But since we are here and are qualified, we have a job and can live, that's why we never bothered. We just leave it as it is. (Interview recorded 9 July 2014)

Although this woman has clearly bought time by opting not to fight for her land rights, it hasn't solved the problem. It remains to be seen how her brothers and sisters, or even her own children in the next generation, will fare. For the opponents of the returnees, for those who do not welcome their relatives from Fiji, the unresolved issue of the legality of existing landholdings continues to resonate.

Fiji-Banabans wishing to reclaim land on Tarawa return to an urban atoll where half of Kiribati's entire population now lives. Here they find themselves competing with a steadily growing local population for land that is often insufficiently documented or under-registered. A consequence of this uncertain status has been an upturn in litigation (see Lodge 1987: 76; Namai 1987: 34, 38-39; Paterson and Itibita 2013: 103-104). ${ }^{8}$ Return mobility to Tarawa by landowners from Rabi is probably contributing to this development. This is well illustrated by the case of an elderly Fiji-Banaban born on Tarawa in 1945, not long before the Banaban community was resettled on Rabi. This man told me how, some years earlier, he had travelled with his wife from Rabi to Tarawa to clarify the status of land inherited through his father's line. As well as having several parcels certified to his name, at the time of our interview he was still embroiled in no less than four legal actions over separate land issues. He stated the following:

My father is a Banaban. Half Banaban, half Gilbertese. So I have to come and search for his land. My father's land. That's why I am staying here now for seven years. I take it to the court. Because we came here and my land was taken by fraud. Was just taken. We don't know how they took it. So we have to take it to the court. We are still in court now ... [And] I've

8 Complicating matters somewhat is the fact that the land register for South Tarawa, which is the most densely populated part of the entire island state, went missing in 1987 in a manner that has never been explained (Paterson and Itibita 2013: 98). 
got more cases. Yes. There are about four. Now I am waiting for the High Court. And more, plenty more to come [laughing]. Yes, because my father had a lot of land here. (Interview recorded 25 July 2014)

In this concrete case, the length of the couple's stay on Tarawa derived less from a desire to settle there permanently than from the time-consuming nature of the endless court battles over land. This impression is backed by the fact that the man's grown-up children had opted, without exception, to remain on Rabi. Moreover, according to both parents, their children regularly urged them to return to Fiji, instead of concerning themselves with endless land squabbles.

Other family groups on Rabi organise the return of members to Tarawa. In such cases, the aim is not simply to get land claims certified, but to take possession of the land and put it to good use. Over the last 10 to 15 years, return mobility has led to Fiji-Banabans of the second and especially the third generation settling on Tarawa. This trend is illustrated by the story of a Fiji-Banaban woman in her mid-30s. Gina is a third-generation RabiBanaban. Her father was chosen by his extended family in the 1990 s to migrate with his wife to Tarawa. The aim of relocation was twofold: to manage the family's landholdings on Tarawa and to remit rents from parcels of land that had been leased out to family members on Rabi. The children, Gina among them, remained on Rabi with relatives, and only after finishing their schooling did they follow their parents. Today Gina lives on Tarawa where she has a good job with a secure future. Asked whether she felt 'at home' there, she stated:

G: Yeah. Like now I can feel that Kiribati is my home ...

WK: What about Rabi then?

G: I don't know. Probably [laughing] we can call it home too because that's where we were brought up. Yeah, but like-right now, all I want to do is visit Rabi ... like for a short term, something like that ... Now I feel that Kiribati is my home. Since we do have a home-our own homehere. We have a house of our own here. (Interview recorded 23 July 2014)

Land ownership, jobs, education—or a combination of all three-have led to a situation where Fiji-Banabans of the third generation acquire island homes on Tarawa. They work, look after their elderly parents (invariably Fiji-Banabans of the second generation), get married (not infrequently to I-Kiribati partners), have a family, help to expand their family networks in Kiribati, and, by return visits to Fiji, maintain contact with relatives there. 
Such island homes, beyond the home islands of Banaba and Rabi, could in the long run broaden the concept of homeland, especially for future generations of Banabans.

\section{Turning again? Fiji-Banabans and discourses on climate change in Kiribati}

But what do long-term Banaban residents on Tarawa think of return mobility? In fact, a number of Fiji-Banaban migrants to Kiribati view it in a positive light. The motives behind this desire to return are often closely dependent on age and the degree of personal attachment to Rabi. This is well illustrated by the case of 67-year-old Natan. He was adamant that he wanted to leave soon for Rabi Island, where he planned to spend his last years. Already, during 2012 and 2013, he had visited his son on Rabi, spending several months on that island; but he had not stayed, returning to Tarawa and his other children. Asked in September 2013 about his future plans, he told me that it was up to his children and their families to decide where, if anywhere, they wanted to migrate to in future, but for him the matter was clear:

$\mathrm{N}$ : [I] will go back to Rabi. So much for me. I've never changed my mind about this. I'll just stay in my home. I want to be buried next to my father and my mother-on Rabi.

WK: But didn't you ever think of Banaba?

$\mathrm{N}$ : Well, no ... Because I wasn't brought up there. I was born on Rabi and was brought up on Rabi. (Interview recorded 28 September 2013)

Like many other Banabans, he viewed his kinship ties with Kiribati-in this case, his ancestors on the Kiribati atoll of Tabiteuea-as central to his personal identity. Therefore, in the context of musing about a return to Rabi, he also entertained thoughts about what the future held for his relatives in Kiribati. The background can be found in official discourses about the possible consequences of climate change and sea-level rise for Kiribati. Though long in circulation and nothing new, such discourses have in recent years weighed increasingly heavily on the population of what is, after all, an atoll state: 
I am thinking of my Kiribati relatives who could then come to Rabi ... [Some are] on Tabiteuea. Some on Tarawa. Some of them are here [Ambo, WK], and some on Eita ... And I worry about them. If there is climate change, where are they going to run to? Where will they run? They have to go [back] to Tabiteuea. [But] Tabiteuea will be just the same. One way or another, [they] will be affected ... Now, there is nothing against them coming to Rabi. (Interview recorded 28 September 2013)

The government of Kiribati, under President Anote Tong, has for many years pursued an active policy of adjustment to the impact of climate change and higher seas. Among the central planks of this policy was, first, the implementation (over the short and medium term) of adaptive measures within the framework of the Kiribati Adaptation Program (KAP), with the primary goal of reducing Kiribati's vulnerability. Despite it being premature to talk of an acute danger from climate change and sealevel rise-despite the alarmist reports circulating in the global media and disseminated by more than a few NGOs - if we take the longer perspective, existential risk to this atoll state cannot be excluded. ${ }^{9}$ The second plank has been neatly encapsulated by President Tong in the motto: 'Migration with Dignity'. Thus, he sought to initiate a long-term process of planned labour migration, designed to prevent uncontrolled migrant flows where émigrés end up in camps, marginalised and impoverished for decades to come.

Fiji-Banabans living on Tarawa are, to be sure, aware of such discourses, countermeasures, developments and scenarios. Yet it is a fact that for many the hazards of global warming are primarily a problem for tomorrow. Gina, the Fiji-Banaban lady of the third generation, who now feels completely at home on Tarawa, saw no immediate threat on the horizon:

Yeah, we have been hearing all about that from other people. Like they were planning to move out, something like that. But to me it's like-it's God's plan [laughing] ... It is not really threatening us. And peoplewhen we were in Fiji-they were always saying that before too many years Kiribati would be under[water], something of that. But so far Kiribati is still developing, [laughing] you know, building more buildings. (Interview recorded 23 July 2014)

9 In any event, recent studies point out that 'atoll islands are robust rather than fragile systems' (McLean and Kench 2015: 456). According to these authors, sea-level rise does not necessarily mean that all atoll islands in the central and western Pacific will be engulfed by the end of the 21 st century. On the other hand, the impact of climate change on Pacific islands and their inhabitants is more complex and cannot be limited solely to sea-level rise (see Lazrus 2012: 288-289). 
As a result, she saw no immediate need to think of emigrating. At the same time, most Banabans living in Kiribati derive comfort from the thought that returning to Rabi or Fiji (or in rare cases, Banaba) will always be there on the table as the safe option, should ever the perils of climate change arrive. Here it may be noted that Fiji-Banabans on Tarawa primarily associate climate change with sea-level rise and the ensuing flooding of low lying atolls. Any risk to their own home islands of Rabi and Banaba-volcanic and raised coral islands, respectively, ${ }^{10}$ and therefore significantly higher-is therefore discounted by most Banabans. Ethnic difference from the I-Kiribati, which Banabans often justified by citing the geographic differences separating Banaba and Rabi from the islands of Kiribati, was only confirmed anew by this discourse of the variable effects of climate change. For these Banabans it was clear that they, unlike the I-Kiribati, would always possess a secure place of refuge, should the worst-case scenario eventuate. Here the Fiji-Banabans on Tarawa chiefly had Rabi Island in mind. Tera, the Fiji-Banaban woman of the third generation who had come to Kiribati more than 10 years earlier, said this:

But when it comes to global warming, to the climate warming up, why then, for us Rabians [or Rabi-Banabans] —we are not too worried, because we have another land in Fiji. That's the main thing, so we never worry about anything. If the time for evacuation ever comes, we just go to our land ... That's how it is with us Rabians, we're never bothered because we've got land of our own. By the time the water rises, [when] the government has to do something and says: 'Okay, it's time to leave Kiribati'. well, we know we have another place to go. We don't know about the Gilbertese. (Interview recorded 9 July 2014)

To take another example, according to a second-generation Banaban, who some 10 years earlier had migrated with his family from Rabi to Kiribati and now lived with two of his sisters and their families (also émigrés from Rabi) on family-owned land on Tarawa:

When I go to bed at night, sometimes I find myself thinking about the sea level. I don't know when my time will come. But when it does, what will happen to my kids? What will they do? So I think we'd better think now

10 Rabi Island in Fiji measures all of 68 square kilometres; it is a high volcanic island with the highest peak, Maungani Banaba, rising more than 460 metres above the waves. Banaba or Ocean Island with an area of 16 square kilometres is somewhat smaller. It is the only raised coral island found in Kiribati with high ground in the order of 80 metres, making it the highest island in this atoll state. By comparison, all of Kiribati's other atolls and reef islands rise by no more than 2 to 3 metres above the ocean. 
about how to protect them ... And yet, we are not so worried after all, we have a homeland, you know, and we have mountains! Just like that, eh?! We do have a homeland! That's why we don't worry or really care about the sea level rising here. Because we have our island Rabi, you know. (Interview recorded 5 September 2009)

In the further course of our conversation, this man emphasised that returning to Rabi was always on the table, it could be done any time, and because this was so, it stripped from an uncertain future some of its power to terrify. He also pointed out that returning was far from the only possible option for him as a Banaban living in Kiribati:

The time is coming close. More people talk about it now because the time is not far off. I've no doubt that the government will do something for the people. That's the government's job. It will do something for the people, and I was telling [my wife], 'Rabi is very close for us, but first we'll listen to the government, where they wanna migrate to.' ... So like if they [government officials] say 'Australia or New Zealand', I will certainly be among them. Right?! That's gonna be important, because this land [knocks the ground] is our mother's land. She's got land here and we are part of the I-Kiribati too. (Interview recorded 5 September 2009)

Owning land on Tarawa allows Banaban migrants to justify their Kiribati identity. They then build on this by affirming their right as citizens to be included in whatever international migration programs the government may one day put in place. For this head of an extended Banaban family living on Tarawa, there is, therefore, no doubt that the government of Kiribati would bear primary responsibility for the population's fate should catastrophe ever strike. While returning to Rabi Island is certainly uppermost in this man's future imaginings, he is careful, on the other hand, not to rule out the chance of migrating to one or other of the metropolitan states in the region, especially if this was promoted by Kiribati's government or organised by those states.

Not all of Tarawa's Banabans find it easy to come to terms with returning to Rabi Island in Fiji, should it come to that. A middle-aged married woman who had grown up on Rabi Island but had lived for many years on Tarawa with her husband, a pastor of the Kiribati Protestant Church, and the children from their union, explained what she thought about returning to Fiji in the following words: 
As for climate change-yeah, we thought about it [return migration]. But being married cuts two ways [laughing]. So we thought about it and we thought, maybe when we retire we can go back to Fiji. But then I thought, my kids are here [in Kiribati] ... If my children are here, they can't go back to Fiji, because they are not Fiji-born. [My husband] is Fiji-born, I am Fiji-born and our eldest son is Fiji-born. So we can go back with one of them. But not with the other two and their children ... It is very hard for me to imagine that I should go back to Fiji because of sea-level rise, when my kids are here. So I might as well let them migrate, do whatever they want. I'll be the last one to leave the ship [laughing]. (Interview recorded 8 October 2013)

The possibility of returning to Fiji (Rabi Island is not explicitly mentioned here) occupies an important place in this woman's speculations about what to do in the future, should climate change and sea-level rise ever seriously imperil her present country of residence, Kiribati. Her view shows that return is a problematic issue, considering the family's differences in citizenship. She will therefore make her final decision contingent on the future abode of her children and grandchildren. In this connection, she hints that migration by family members to another country is likely, indeed probable, over the medium to long term. But only when she knows her own family would be safe, so her thinking goes, could she decide where to go herself.

These Banaban discourses envisioning a future of international return migration from Tarawa to Rabi, or, more generally, to Fiji, afford insights into variable motives and multiple scenarios. Two basic positions are evident in this connection. On the one hand, Rabi is affirmed as a place of belonging, as home island, as somewhere to retire to and a peaceful haven in old age. On the other hand, within the context of discourses on the future consequences of climate change and sea-level rise, Banaban migrants on Tarawa see Rabi Island or Fiji as a potential place of refuge for themselves and their I-Kiribati relatives. Even so, they do not exclude the option of international migration to the metropolitan states of the region.

\section{Conclusion}

From a historical perspective, return mobility for the resettled Banabans is a multidirectional phenomenon with multiple destinations. When community leadership was locked in an anticolonial struggle for financial compensation, rehabilitation of all areas affected by mining, and national sovereignty, return to Banaba loomed large. The first generation was able 
to mobilise the then still-young second generation for their political aims of collective return and organised occupation of their ancestral home. Since that time, the community's claim to Banaba is primarily upheld by the routines of return of employees of the Rabi Council of Leaders in Fiji, while, at the same time, Kiribati exercises state control through its own on-site representatives.

Banaba continues to function for the Banaban diaspora as an important point of historical and political reference for ethnic identification and cultural belonging. That said, the home island is not a primary destination for return migration by the next generations. True, the pioneer generation, with its politics of transcolonial linkage between Rabi and Banaba, was determined to anchor the latter in the community's collective memory; yet, in achieving this goal, they inadvertently paved the way for a diversification of return by the second and third generations. Without actually questioning the congruence between home island and homeland, the second and third generations are, in fact, able to tap into the enlarged spectrum of opportunities resulting from the transnational belonging to Fiji and Kiribati. Reversal and ramification are important principles in this process.

Recent migration by Fiji-Banabans to Kiribati is an exemplary case of what I mean by ramification of return. Thus the returnees from Fiji, when choosing where to build their island home, usually look now beyond the home island of Banaba to the capital atoll of Tarawa. This is chiefly prompted by a desire for improved access to social, cultural and economic resources in a transparent urban environment. Having island homes on Tarawa may one day serve to redefine what homeland means to future generations of Banabans born in Kiribati. Being based there may, in individual cases, even serve as a springboard for further migration, this time to the ambient metropolitan states of the Pacific region. At present, though, a lot of these Banaban island homes point toward a reversal of return mobility. Hence, for the majority of second-and third-generation Fiji-Banabans living on Tarawa, Rabi Island remains the primary home island and preferred place of return. Whether it takes the form of brief visits, longer stays, concrete plans to return or an imagined safe haven, a place of refuge, in the event of future fallout from climate change and sea-level rise, return to Rabi Island resonates strongly with Banabans dwelling on Tarawa. By contrast, Banaba has slipped increasingly into the background, albeit without losing its elemental function as ancestral homeland. 
The historical sequence of displacement, collective resettlement, translocal linkages, international migration and transnational relations has given rise to a specific genealogy of return. The strategic duality of belonging, which the first generation of resettled Banabans bequeathed to the next generations, constitutes a fundamental ordering principle. At the same time, it is the motor driving diversification of return. Of especial note is that the continued reticulation of home islands fosters (reverse) transnationalism, which lets the second and third generations extend belonging to a larger field of island homes. Thus the analysis of Banaban return mobility indicates the seminal importance of seeing homelands and movements from a historical perspective, the better to locate (and understand) diversification of return in a shifting terrain of colonial and postcolonial structures.

\section{Acknowledgements}

I am particularly indebted to the members of Banaban community on Tarawa in Kiribati who shared with me their stories, experiences and views in connection with return mobility. My special thanks to Steffen Herrmann for preparing the map. For their reading of and valuable suggestions to an earlier version of my paper I wish to thank Leslie Butt, Jenny Munro, Helen Lee and Jack Taylor. To Elfriede Hermann my particular thanks for her insightful critiques and support. Responsibility for the views in this article is, of course, mine alone.

\section{References}

'Banabans seek better phosphate deal' 1965, Pacific Islands Monthly, November, p. 17.

'Banabans set sail for their island home' 1975, The Fiji Times, March 10.

Binder, P 1977, Treasure islands: the trials of the Ocean Islanders, Blond and Briggs, London.

Brettell, CB 2015, 'Theorizing migration in anthropology', in CB Brettell \& J Hollifield (eds), Migration theory: talking across disciplines, 3rd edition, Routledge, New York and London, pp. 148-197. 
Cassarino, J-P 2004, 'Theorising return migration: the conceptual approach to return migrants revisited', International Journal on Multicultural Societies, vol. 6, no. 2, pp. 253-279.

Cernea, MM \& McDowell, C (eds) 2000, Risks and reconstruction: experiences of resettlers and refugees, The World Bank, Washington DC doi.org/10.1596/0-8213-4444-7

Conway, D \& Potter, RB 2009a, 'Return of the next generations: transnational migration and development in the 21st century', in D Conway \& RB Potter (eds), Return migration of the next generations: 21st century transnational mobility, Ashgate, Farnham, England and Burlington, VT, pp. 1-18.

Conway, D \& Potter, RB 2009b, 'Return of the next generations: transnational mobilities, family demographics and experiences, multilocal spaces', in D Conway \& RB Potter (eds), Return migration of the next generations: 21st century transnational mobility, Ashgate, Farnham, England and Burlington, VT, pp. 223-242.

Dagmar, H 1989, 'Banabans in Fiji: ethnicity, change, and development', in M Howard (ed.), Ethnicity and nation-building in the Pacific, The United Nations University, Tokyo, pp. 198-217.

Ellis, AF 1935, Ocean Island and Nauru: their story, Angus and Robertson Ltd, Sydney.

Ellis, AF 1946, Mid-Pacific outposts, Brown and Stewart Ltd, Auckland.

Foreign and Commonwealth Office 1968, The Ocean Island Phosphates Discussions, October 1968, Foreign and Commonwealth Office, London.

Glick Schiller, N \& Salazar, NB 2013, 'Regimes of mobility across the globe', Journal of Ethnic and Migration Studies, vol. 39, no. 2, pp. 183-200. doi.org/10.1080/1369183X.2013.723253

Hermann, E 2003, 'Manifold identifications within differentiations: shapings of self among the relocated Banabans of Fiji', Focaal, vol. 42, pp. 77-88.

Hermann, E 2004, 'Emotions, agency and the dis/placed self of the Banabans in Fiji', in T van Meijl \& J Miedema (eds), Shifting images of identity in the Pacific, KITLV Press, Leiden, pp. 191-217. 
Hermann, E 2006, 'Korrelationen von Verschiedensein und Gleichsein als Ko-Differenz: Selbst und Ethnie bei den Banabans in Fiji', University of Göttingen: Habilitation Thesis.

Hermann, E \& Kokoria, TT 2005, 'Feelings of connectedness - the Banabans and their home islands', in J Shennan \& MC Tekenimatang (eds), One and a half Pacific Islands: stories the Banaban people tell of themselves, Victoria University Press, Wellington, pp. 128-129.

Kempf, W 2004, 'The drama of death as narrative of survival: dance theatre, travelling and thirdspace among the Banabans of Fiji, in $T$ van Meijl \& J Miedema (eds), Shifting images of identity in the Pacific, KITLV Press, Leiden, pp. 159-189.

Kempf, W 2011, Translocal entwinements: towards a history of Rabi as a plantation island in colonial Fiji. GOEDOC, Dokumenten- und Publikationsserver der Georg-August-Universität.

Kempf, W 2012, 'A promised land in the diaspora: Christian religion, social memory, and identity among Banabans in Fiji', Pacific Studies, vol. 35, no. 1/2, pp. 90-118.

Kempf, W \& Hermann, E 2005, 'Reconfigurations of place and ethnicity: positionings, performances and politics of relocated Banabans in Fiji', Oceania, vol. 75, no. 4, pp. 368-386. doi.org/10.1002/j.18344461.2005.tb02897.x

King, R \& Christou, A 2014, 'Of counter-diaspora and reverse transnationalism: return mobilities to and from the ancestral homeland', in R King, A Christou \& P Levitt (eds), Links to the diasporic homeland: second generation and ancestral 'return' mobilities, Routledge, London and New York, pp. 1-16.

Lazrus, H 2012, 'Sea change: island communities and climate change', Annual Review of Anthropology, vol. 41, pp. 285-301. doi.org/10.1146/ annurev-anthro-092611-145730

Lee, H 2003, Tongans overseas: between two shores, University of Hawai' $\mathrm{i}$ Press, Honolulu.

Lee, H 2009, 'The ambivalence of return: second-generation Tongan returnees', in D Conway \& RB Potter (eds), Return migration of the next generations: 21st century transnational mobility, Ashgate, Farnham, England, Burlington, VT, pp. 41-58. 
Lodge, M 1987, 'Land law and procedure', in R Crocombe (ed.), Land tenure in the atolls: Cook Islands, Kiribati, Marshall Islands, Tokelau, Tuvalu, University of the South Pacific, Suva, pp. 73-107.

Macdonald, BK 1982, Cinderellas of the empire: towards a history of Kiribati and Tuvalu, Australian National University Press, Canberra.

Maude, HE 1946, Memorandum on the future of the Banaban population of Ocean Island: with special relation to their lands and funds, Western Pacific High Commission, Suva.

McLean, R \& Kench, P 2015, 'Destruction or persistence of coral atoll islands in the face of 20th and 21st century sea-level rise?', WIREs Climate Change, vol. 6, September/October, pp. 445-463. doi.org/ $10.1002 /$ wcc. 350

Namai, B 1987, 'The evolution of Kiribati tenures', in R Crocombe (ed.), Land tenure in the atolls: Cook Islands, Kiribati, Marshall Islands, Tokelau, Tuvalu, University of the South Pacific, Suva, pp. 30-39.

National Archives of Fiji (NAF) High Court of Justice 1968, Documents 46/1968. Memorandum on Petition of the Banaban People Presented to the United Nations Committee of Twenty-Four (5 June 1968).

'Ocean Island welcomes 60 from Fiji: Rabi settler group stays' 1975, The Fiji Times, March 24.

Oliver-Smith, A 2009a, 'Introduction. Development-forced displacement and resettlement: a global human rights crisis', in A Oliver-Smith (ed.), Development and dispossession: the crisis of forced displacement and resettlement, School for Advanced Research Press, Santa Fe, pp. 3-23.

Oliver-Smith, A 2009b, 'Climate change and population displacement: disasters and diasporas in the twenty-first century', in S Crate \& $\mathrm{M}$ Nuttall (eds), Anthropology and climate change: from encounters to actions, Left Coast Press, Walnut Creek, pp. 116-136.

Paterson, D \& Itibita, B 2013, 'Kiribati', in D Paterson \& S Farran (eds), South Pacific land systems, USP Press, Suva, pp. 93-105.

'Petrol bombs on Banaba’ 1979, Pacific Islands Monthly, April, p. 22. 
Posnett, RN 1977, 'Ocean Island and the Banabans: a report to the Minister of State for Foreign and Commonwealth Affairs', London, Manuscript.

Potter, RB, Conway, D \& Phillips, J (eds) 2005, The experience of return migration: Caribbean perspectives, Ashgate, London.

Reynolds, T 2014, 'Caribbean second-generation return migration: transnational family relationships with "left-behind" kin in Britain', in R King, A Christou \& P Levitt (eds), Links to the diasporic homeland: second generation and ancestral 'return' mobilities, Routledge, London and New York, pp. 85-101.

Secretariat of the Pacific Community 2007, 'Kiribati 2005 Census. Volume 2: Analytical Report', Statistics and Demography Programme and Kiribati Statistics Office, Noumea, New Caledonia.

Silverman, MG 1971, Disconcerting issue: meaning and struggle in a resettled Pacific community, The University of Chicago Press, Chicago and London.

Teaiwa, KM 2014, Consuming Ocean Island: stories of people and phosphate from Banaba, Indiana University Press, Bloomington and Indianapolis.

Teaiwa, TK 1997, 'Rabi and Kioa: peripheral minority communities in Fiji', in BV Lal \& TR Vakatora (eds), Fiji in transition, Research Papers of the Fiji Constitution Review Commission, vol. 1, The University of the South Pacific, Suva, pp. 130-152.

Williams, M \& MacDonald, B 1985, The Phosphateers: a history of the British Phosphate Commissioners and the Christmas Island Phosphate Commission, Melbourne University Press, Carlton.

Wimmer, A \& Glick Schiller, N 2002, 'Methodological nationalism and beyond: nation-state building, migration and the social sciences', Global Networks, vol. 2, no. 4, pp. 301-334. doi.org/10.1111/14710374.00043 
This text is taken from Mobilities of Return: Pacific Perspectives, edited by John Taylor and Helen Lee, published 2017 by ANU Press, The Australian National University, Canberra, Australia.

dx.doi.org/10.22459/MR.12.2017.02 